\title{
Jenis Kekeliruan Akibat Menghafal Prosedur Rutin DAlam MELAKUKAN OPERASi PENJUMLAhAN DAN Pengurangan Bilangan Pecahan
}

\author{
THE TyPES of ERRor DUE MEMorize Routine Procedure in DoING \\ ADDITION AND SUBTRACTION OPERATION OF FRACTION NUMBERS
}

\author{
Sri Imelda Edo \\ Politeknik Pertanian Negeri Kupang \\ Kupang, Indonesia \\ sriimeldaedo@yahoo.com
}

\begin{abstract}
Abstrak
Berdasarkan pengalaman penulis sebelumnya ketika mengajar matakuliah matematika dasar pada jurusan TPH Politani Kupang, mahasiswa selalu mengalami kesulitan dalam operasi bilangan pecahan. Karena itu pada saat proses pembelajaran, pengajar terpaksa harus kembali memberikan penanaman konsep bilangan pecahan. Kondisi ini menarik perhatian penulis untuk mengidentifikasi jenis-jenis kekeliruan mahasiswa baru jurusan TPH Politani Kupang tahun 2015 dalam melakukan operasi penjumlahan dan pengurangan pecahan dan faktor penyebabnya. Proses investigasi ini dilakukan melalui metode penelitian kualitatif. Data dikumpulkan melalui tes tertulis dan wawancara. Hasilnya adalah; 5\% mahasiswa langsung menjumlahkan bagian Pembilang dengan pembilang dan Penyebut dengan penyebut dari dua bilangan pecahan yang berbeda penyebut. 3\% mahasiswa langsung menjumlahkan penyebut yang berbeda dari dua bilangan pecahan yang pembilangnya sama. $83 \%$ mahasiswa menyamakan penyebut dari bilangan pecahan dengan menggunakan KPK tetapi mereka lupa cara merubah pembilang apabila penyebutnya berubah. 5\% mahasiswa menyelesaikan soal dengan menggunakan rumus, namun mereka menggunakan rumus operasi perkalian pada operasi pengurangan. Sisahnya $4 \%$ mahasiswa menjawab benar dengan cara menyamakan penyebut dengan menggunakan KPK. Sementara hasil wawancara menunjukan bahwa dominan mahasiswa merupakan tamatan SMK dan berasal dari kabupaten yang tersebar diseluruh wilayah propinsi NTT. Mereka hanya mengenal dua cara melakukan operasi pecahan yaitu menyamakan penyebut dengan KPK dan mengunakan rumus. Kedua cara ini memiliki algoritma baku yang harus mereka hafal. Mereka tidak memahami apapun dibalik langkah demi langkah dalam algoritma tersebut. Dengan demikian semua jenis kekeliruan di atas merupakan akibat dari menghafal prosedur rutin yang mereka pelajari pada jenjang pendidikan sebelumnya.
\end{abstract}

Kata Kunci: Operasi Pecahan, Miskonsepsi pecahan, penjumlahan pecahan, pengurangan pecahan, akibat menghafal rumus.

\begin{abstract}
Based on Authors experience when taught basic math course, in general students have found difficulty in operating fractions. Therefore, the goal of this research was to investigate student's errors and misconception in addition and subtraction of fraction. Research conducted at Aqua Culture Technology, Agriculture industry technology study programs food Crops and horticulture Department of POLITANI Kupang on 2015. New students were the subjects of this study. This process is done through qualitative research methods. Data were collected through written tests and interviews. However, some students can solve formal operation given in common rule without
\end{abstract}


any sense of its concept. The result were; $5 \%$ of the students added the numerator and denominator of the fractions directly even the denominators are different, $3 \%$ of students equate the numerator of fractions and then add them together. $83 \%$ of students equate the denominator of the fractions using least common multiple but they forget how to change the numerator of those fractions when their denominator was changed. 5\% of students solved problems using the formula given by teacher, but they failed to remember it well. The rest $4 \%$ of students can solve the question correctly. While the interviews results showed that dominant students are graduates from Vocational high School and come from districts that are spread throughout the province of NTT. They only knew two ways in addition and subtraction of fractions i.e. equate denominators of fractions using least common multiple and using formula. Both of them has a standard algorithm that students have to memorized. They do not understand anything about step by step of the algorithm. Thus all kinds of errors was the effect of memorizing the routine procedures they learned in the previous education level.

Keyword: Fractions operation, misconceptions of fractions, fractions addition, subtraction of fractions, memorize formulas in operate fraction.

\section{Pendahuluan}

Meskipun bilangan pecahan memegang peranan penting dalam pengembangan berbagai cabang ilmu matematika dan bahkan untuk kemajuan ilmu pengetahuan dan teknologi, namun pemahaman tentang bilangan pecahan ini masih belum clear baik oleh siswa, mahasiswa maupun guru. Lamon mengatakan bahwa pemahaman tentang bilangan pecahan merupakan dasar utama dalam membangun dan mengembangkan pemahaman tentang perbandingan [1]. Selanjutnya ia mengatakan bahwa sudah jelas bahwa guru mengalami kesulitan untuk memahami dan mengajarkan pecahan. Demikian juga menurut Clark et. al. mengatakan bahwa banyak siswa mengalami kesulitan dalam mempelajari bilangan pecahan karena banyaknya interpretasi, representasi, model dan konversi yang berbeda dalam penggunaan pecahan [2]. Masalah ini juga telah dikemukakan oleh De Castro bahwa banyak guru mampu melakukan operasi pecahan tetapi tidak memahami konsep pecahan. [3]
Nenden mengatakan bahwa dalam pembelajaran pecahan di Indonesia, siswa diminta untuk menyelesaikan masalah tentang perkalian pecahan dengan menggunakan prosedur dan algoritma yang diajarkan guru [4]. Mereka hanya menghafal rumus dan cara berhitung untuk dapat menyelesaikan masalah pecahan. Karena itu kita tidak tahu apakah mereka mengerti makna yang terkandung dalam prosedur-prosedur itu atau tidak. Sedangkan Surya juga mengatakan bahwa banyak guru Sekolah Dasar (SD) yang belum memahami konsep pecahan, bahkan masih terdapat guru SD di pedalaman yang belum mampu melakukan operasi pecahan. [5]

Berdasarkan Pengalaman penulis pada saat mengajarkan matakuliah matematika pada mahasiswa semester I program Studi Tanaman pangan dan Hortikultura, Program studi Teknologi Pengolahan Pangan, dan semester II program studi Teknologi Industri Hortikultura, yang berada pada jurusan tanaman pangan dan hortikultura (TPH), bahwa ketiga program studi ini pada umumnya mengalami masalah yang sama yaitu; mahasiswa 
mengalami kesulitan dalam memahami konsep Pecahan, dan masih banyak yang belum bisa melakukan operasi Pecahan. Meskipun terdapat mahasiswa yang mampu melakukan operasi pecahan tetapi mereka tidak sepenuhnya memahami konsep pecahan. Mereka yang mampu melakukan operasi pecahan adalah mereka yang masih mengingat prosedur atau algoritma yang diajarkan oleh guru. Kesalahan yang paling banyak dilakukan oleh mahasiswa di sini adalah pada operasi penjumlahan dan pengurangan. Karena itu, pada tahun 2015 ini sebelum mengajarkan materi pecahan peneliti terlebih mengidentifikasi miskonsepsi, jenis kesalahan mahasiswa dalam melakukan operasi penjumlahan pecahan.

Mempelajari Matematika tidak bisa terlepas dari bilangan. Salah satu bagian dari klasifiksi bilangan adalah bilangan pecahan. Bilangan pecahan ini sudah diajarkan di jenjang SD kelas 3 semester II.

Kata pecahan berarti bagian dari keseluruhan yang berukuran sama berasal dari bahasa Latin fractio yang berarti memecah menjadi bagian-bagian yang lebih kecil.

Berdasarkan pengertian di atas, Freudenthal mendefinisikan pecahan dalam 4 aspek yaitu aspek yang pertama adalah pecahan diangggap sebagai sebagai fracturer (pecah) [6]. Aspek yang lainnya adalah pecahan sebagai pembanding, pecahan sebagai operator, dan pecahan sebagai bagian dari keseluruhan yang dibagi sama banyak.

Secara simbolik pecahan dapat dinyatakan sebagai salah satu dari:
1. Pecahan Biasa,

2. Pecahan desimal,

3. Pecahan persen,

4. Pecahan Campuran.

Menurut Kennedy Makna Pecahan dapat muncul dalam situasi-situasi seperti ini: [7]

1. Pecahan sebagai bagian yang berukuran sama dari yang utuh atau keseluruhan.

2. Pecahan biasa dapat digunakan untuk menyatakan makna dari setiap bagian dari yang utuh. Apabila ibu mempunyai sebuah roti yang akan diberikan kepada 4 orang anggota keluarganya maka masing-masing harus mendapat bagian yang sama yaitu $\frac{1}{4}$ bagian. Bagianbagian dari sebuah pecahan biasa menunjukkan hakikat situasi dimana lambang bilangan tersebut muncul. Dalam lambang bilangan $\frac{1}{4}, 4$ menunjukkan banyaknya bagian-bagian yang sama dari satu yang utuh dan disebut sebagai 'Penyebut '. Sedangkan 1 menunjukkan banyaknya bagian yang menjadi perhatian pada saat tertentu dan disebut sebagai pembilang.

3. Pecahan Sebagai bagian dari kelompokkelompok yang beranggotakan sama banyak atau juga menyatakan Pembagian

4. Apabila sekumpulan Objek dikelompokkan menjadi bagian yang beranggotakan sama banyak, maka situasinya jelas dihubungkan dengan pembagian. Situasi dimana sekumpulan objek yang beranggotakan sama banyak, maka kalimat matematikanya dapat $12: 2=$ atau $\frac{1}{2} x 12=6$. Sehingga untuk mendapatkan $\frac{1}{2}$ dari 12 maka 
anak harus memikirkan 12 objek yang dikelompokkan menjadi 2 bagian yang beranggotakan sama.

5. Pecahan Sebagai Perbandingan (Rasio) Hubungan antara sepasang bilangan sering dinyatakan sebagai sebuah perbandingan. Misalnya dalam satu kelompok yang terdiri dari 10 buku, terdapat 3 buku bersampul biru. Rasio buku yang bersampul biru terhadap keseluruhan buku adalah 3:10 atau buku yang bersampul biru adalah $\frac{3}{10}$ dari keseluruhan buku.

\section{Metode}

Metode Penelitian yang digunakan dalam penelitian ini adalah Penelitian Kualitatif murni yang dilakukan melalui tahap-tahap sebagai berikut;

1. Identifikasi fenomena atau situasi yang akan dipelajari. Masalah yang alami oleh Mahasiswa jurusan TPH program studi TPH, TIH, TPG., angkatan 2014 adalah masih ada mahasiswa yang belum bisa melakukan operasi pecahan. Mereka belum memahami konsep pecahan, bahkan dominan mahasiswa belum mengerti makna pembilang dan penyebut karena di SD mereka langsung diberitahu bahwa angka yang di atas disebut sebagai pembilang dan angka yang di bawah disebut sebagai penyebut. Guru lebih banyak mengajarkan prosedur rutin tanpa melakukan penanaman konsep pecahan.

2. Mengidentifikasi peserta yang akan terlibat dalam penelitian atau sebagai subjek penelitian, sample penelitian ditentukan dengan menggunakan metode purposive sampling, yaitu mahasiswa program studi Teknologi budidaya perikanan (TBP) semester 1 tahun 2015 yang terdiri dari 27 orang, dan mahasiswa program studi TPH sebanyak 39 orang. Pertimbangannya adalah bahwa matakuliah matematika pada kedua program studi ini diajarkan pada semester I. Artinya mahasiswa masih memiliki status mahasiswa baru atau belum mendapat tambahan pengetahuan berarti dari perguruan tinggi. Sedangkan program studi $\mathrm{TIH}$ menempatkan matakuliah matematika pada semester II. Sementara program studi TPG menerapkan system Blok dimana matakuliah matematika diajarkan pada bulan januari. Dengan demikian mahasiswa sudah mendapat banyak tambahan ilmu pengetahuan di perguruan tinggi dan mereka tidak lagi berstatus mahasiswa baru. Karena sesuai dengan tujuan penelitian untuk mengetahui jenis kekeliruan mahasiswa baru dalam melakukan operasi pecahan.

3. Merumuskan Hipotesis. Hipotesis dalam penelitian ini adalah mahasiswa baru program studi TPH, dan TBP tidak memahami konsep pecahan, dan melakukan operasi pecahan hanya dengan menghafal prosedur rutin yang diajarkan guru.

4. Pengumpulan data, Data dikumpulkan dengan menggunakan metode tes tertulis, wawancara dokumentasi berupa foto, video, dan catatan lapangan.

5. Analisis Data, Data dianalisis secara deskripsi tentang apa yang telah diamati dan ditemukan dari keseluruhan proses penelitian. 
6. Interpretasi hasil dan buat kesimpulan. Kesimpulan akhir dari proses kegiatan sesuai dengan tujuan penelitian.

\section{Hasil dan Pembahasan}

Fokus penelitian ini adalah untuk mengetahui pemahaman mahasiswa Semester 1 atau mahasiswa baru tentang Konsep Pecahan dan operasi penjumlahan dan pengurangan pecahan, maka tahap pertama mahasiswa diminta untuk menyelesaikan soal tentang operasi pecahan.

1. $\frac{1}{4}+\frac{1}{2}=\cdots$

2. $\frac{1}{2}+\frac{1}{4}+\frac{1}{16}=\cdots$

3. $\frac{3}{16}+\frac{3}{4}=\cdots$

4. $\frac{1}{2}-\frac{3}{4}=\ldots$

5. $\frac{1}{2}-\frac{1}{3}=\cdots$

Adapun jenis-jenis kekeliruan atau kesalahan mahasiswa dalam menyelesaiakan operasi penjumlahan dan pengurangan adalah:

1. Mahasiswa Langsung Menjumlahkan dan mengurangkan Pembilang dan Penyebut

a. Mahasiswa Langsung Menjumlahkan Pembilang dan Penyebut

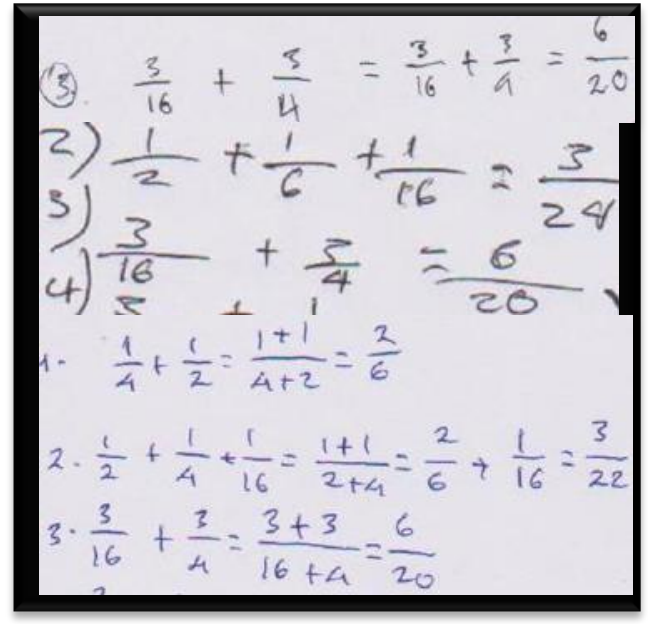

b. Mahasiswa Langsung mengurangkan Pembilang dan Penyebut

$$
\begin{aligned}
& \text { 4. } \frac{3}{4}-\frac{1}{2}=\frac{3-1}{4-2}=\frac{2}{2} \\
& 5 \frac{3}{4}-\frac{1}{16}=\frac{3-1}{4-16}=\frac{2}{22}
\end{aligned}
$$

2. Mahasiswa langsung menjumlahkan penyebut yang berbeda dari kedua bilangan pecahan yang pembilangnya sama.

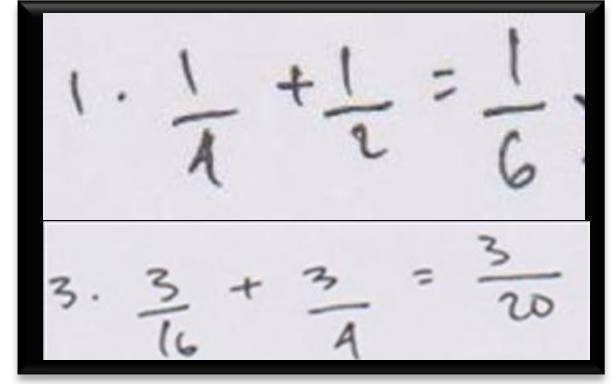

3. Mahasiswa berusaha menyamakan penyebut dengan menggunakan KPK dari pecahan yang dijumlahkan tetapi mereka melupakan prosedur merubah pembilang ketika penyebutnya berubah. 


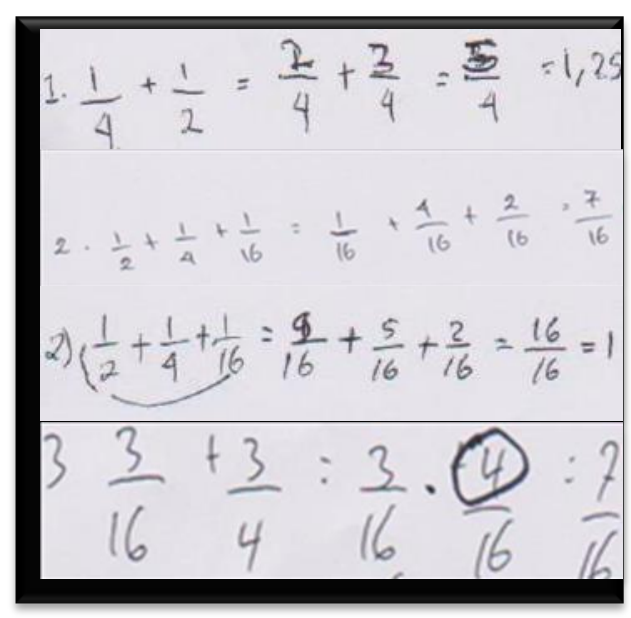

4. Mahasiswa mampu menyamakan Penyebut dengan benar menggunakan KPK, namun mereka menjumlahkan lagi penyebut yang sudah sama tersebut.

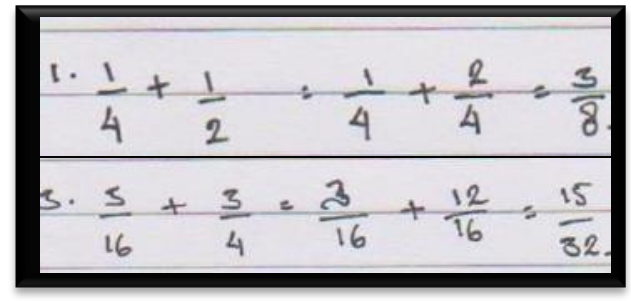

5. Mereka terkecoh dengan rumus yang diajarkan guru sebagai cara lain menyelesaikan pecahan yang berbeda penyebut yaitu sebagai berikut.

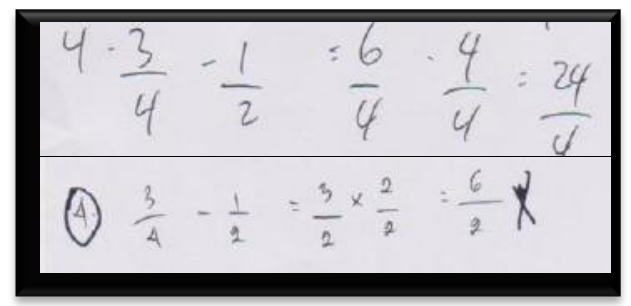

Berdasarkan jawaban mahasiswa di atas, maka peneliti mengivestigasi lebih lanjut dengan melakukan wawancara terhadap beberapa mahasiswa yang memiliki kekeliruan dan juga kepada mahasiswa yang memiliki jawaban yang benar. Hasilnya adalah mahasiswa mengalami kesulitan dalam mengingat prosedur penjumlahan dan pengurangan yang diberikan guru. Menurut mereka operasi penjumlahan dan pengurangan memiliki prosedur yang lebih panjang daripada operasi perkalian dan pembagian. Berikut adalah rincian algoritma penjumlahan dan pengurangan bilangan pecahan yang diajarkan guru mereka pada jenjang pendidikan SD.

Prosedur Penjumlahan yang diajarkan guru:

1. Jika bilangan pecahan yang akan dijumlahkan atau dikurangkan memiliki penyebut yang sama, maka pembilang dari pecahan langsung dijumlahkan, sedangkan penyebutnya adalah penyebut dari bilangan pecahan mulamula.

2. Jika bilangan pecahan yang akan dijumlahkan atau dikurangkan memiliki penyebut yang berbeda, maka penyebut dari pecahan disamakan terlebih dahulu dengan cara sebagai berikut;

a. Mencari kelipatan persekutuan terkecil (KPK) dari penyebut pecahan yang ingin dijumlahkan.

b. KPK tersebut menjadi penyebut dari kedua pecahan.

c. Kemudian KPK dibagi dengan penyebut bilangan pecahan mula-mula.

d. Hasil pembagian KPK dengan penyebut dari masing-masing bilangan pecahan tersebut kemudian dikalikan dengan pembilang mereka masing-masing.

e. Hasil perkalian tersebut kemudian menjadi pembilang dari masing-masing bilangan pecahan.

f. Penjumlahan pembilang dari bilangan pecahan tersebut menjadi pembilang 
dari bilangan pecahan hasil penjumlahan, sedangkan penyebutnya adalah KPK dari kedua penyebut bilangan pecahan.

Sedangkan algoritma dengan menggunakan rumus adalah sebagai berikut;

1. $\frac{a}{b}+\frac{c}{d}=\frac{(a x d)+(b x c)}{b x d}$,

2. $\frac{a}{b}-\frac{c}{d}=\frac{(\text { axd })-(b x c)}{b x d}$,

3. $\frac{a}{b} x \frac{c}{d}=\frac{a x c}{b x d}$,

4. $\frac{a}{b}: \frac{c}{d}=\frac{a x d}{b x c}$, atau $\frac{a}{b}: \frac{c}{d}=\frac{a}{b} x \frac{d}{c}=\frac{a x d}{b x c}$

Berdasarkan hasil tes dan wawancara di atas, dapat diketahui bahwa kekeliruan yang dilakukan mahasiswa adalah karena mereka salah mengingat prosedur atau algoritma yang diajarkan guru kepada mereka. Hal ini dapat dilihat pada kekeliruan jenis pertama yaitu mahasiswa langsung menjumlahkan pembilang dan penyebut dari bilangan pecahan meskipun penyebutnya berbeda. Hal ini terjadi karena mereka sama sekali melupakan algoritma yang diajarkan guru. Untuk itu, mereka mengerjakan seadanya saja.

Sedangkan jenis kesalahan yang kedua yaitu mereka langsung menjumlahkan penyebut yang berbeda dari bilangan pecahan yang pembilangnya sama. Kekeliruan ini terjadi karena mahasiswa mengingat terbalik algoritma penjumlahan bilangan pecahan yang berpenyebut sama. mereka terkecoh dengan "memiliki penyebut sama" dengan yang "memiliki pembilang sama" sebagai berikut:

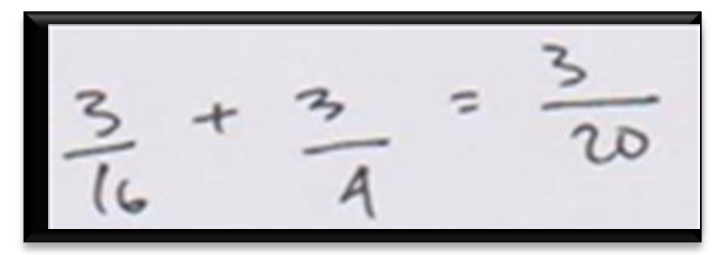

Pada kekeliruan yang ketiga merupakan jenis kekeliruan yang paling banyak dilakukan oleh mahasiswa, dimana mahasiswa mengingat bahwa jika bilangan pecahan yang akan dijumlahkan memiliki penyebut yang berbeda, maka salah satu cara yang harus dilakukan adalah menyamakan penyebut dengan menggunakan KPK. Di sini terlihat bahwa mahasiswa dapat menentukan KPK dari penyebut yang berbeda tersebut. Namun mereka melupakan langkah selanjutnya yaitu menyesuaikan pembilang dengan penyebut yang sudah berubah tersebut sesuai dengan algortima yang diajarkan guru. Perhatikan pekerjaan mahasiswa berikut ini:

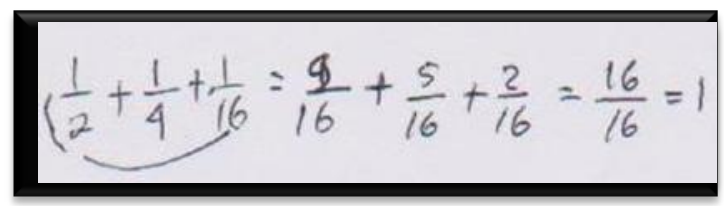

Mahasiswa menyamakan penyebut dengan 16 yang merupakan KPK dari 2, 4, dan 16. Langkah selanjutnya adalah mereka membagikan KPK 16 dengan masing-masing penyebut dari pecahan untuk mendapatkan pembilang, yaitu 16 : $2=8$, selanjutnya 8 dijumlahkan dengan pembilang dari pecahan mula-mula yaitu 1 sehingga $8+1=9$. Dengan demikian pembilang dari bilangan pecahan pertama adalah 9, demikian seterusnya dengan bilangan kedua dan ketiga. Yaitu $16: 4=$ 4 , kemudian $4+1=5$. Pembilang dari bilangan berikutnya adalah $16: 16=1$, dan $1+1=2$. Maka terlihat bahwa pembilang dari bilangan pecahan berturutturut adalah 9, 4, dan 2. Mereka terkecoh pada langkah ke 2d. Langkah yang 
seharusnya dikalikan mereka mengingatnya sebagai penjumlahan.

Selanjutnya dapat diperhatikan pada pekerjaan mahasiswa berikut ini:

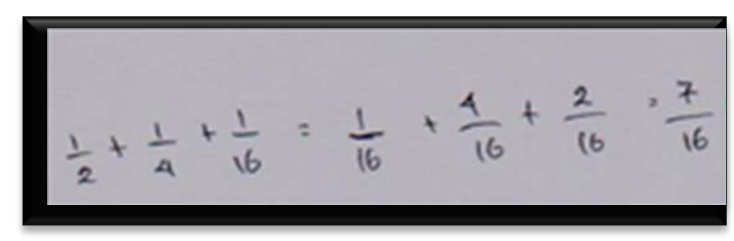

Mahasiswa mampu menentukan KPK dari 2, 4, dan 6. Masalahnya adalah mereka bingung menentukan pembilang dari bilangan pecahan yang penyebutnya tidak sama dengan KPK, seperti $\frac{1}{2}$, dan $\frac{1}{4}$. Untuk pembilang dari masing-masing bilangan pecahan ini, mereka mengalikan penyebut mula-mula dengan pembilang sehingga menjadi $\frac{2}{16}$, dan $\frac{4}{16}$. Sedangkan bilangan yang penyebutnya sudah sama dengan KPK, pembilangnya tetap atau tidak berubah yaitu $\frac{1}{16}$.

Masih sekitar menyamakan penyebut dengan menggunakan KPK, mahasiswa melakukan kesalahan yang hamper serupa dengan yang sebelumnya. Perhatikan pekerjaan mahasiswa berikut ini:

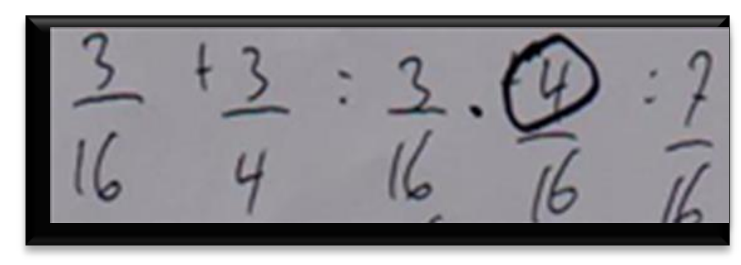

Seperti sebelumnya mereka dapat menentukan KPK. Mereka juga mengingat satu aturan yang diajarkan guru bahwa bilangan yang penyebutnya sama dengan KPK, pembilangnya tidak perlu di rubah lagi, dalam hal ini $\frac{3}{16}$ akan tetap menjadi $\frac{3}{16}$ karena KPK dari 16 dan 4 adalah 16. Mereka juga mengingat langkah 230 selanjutnya bahwa pembilang dari bilangan yang penyebutnya tidak sama akan berubah dengan cara membagi KPK dengan penyebut mula-mula yaitu $16: 4=$ 4. Namun mahasiswa yang bersangkutan lupa satu langkah yaitu mengalikan lagi hasil pembagian tersebut dengan pembilang mula-mula yaitu 3 Sehingga $\frac{3}{4}$ menjadi $\frac{12}{16}$. Tetapi mahasiswa di sini langsung menuliskan hasil pembagian tersebut sebagai pembilang dari bilangan pecahan tanpa harus mengalikannya dengan pembilang mula-mula dapat dilihat dari pekerjaannya yaitu $\frac{3}{4}$ menjadi $\frac{4}{16}$.

Jenis kekeliruan yang keempat merupakan jenis kekeliruan yang lebih kecil dibandingkan dengan kekeliruan sebelumnya. Karena disini mahasiswa mengingat lebih banyak langkah atau prosedur yang diajarkan guru. Perhatikan pekerjaan mahasiswa berikut ini:

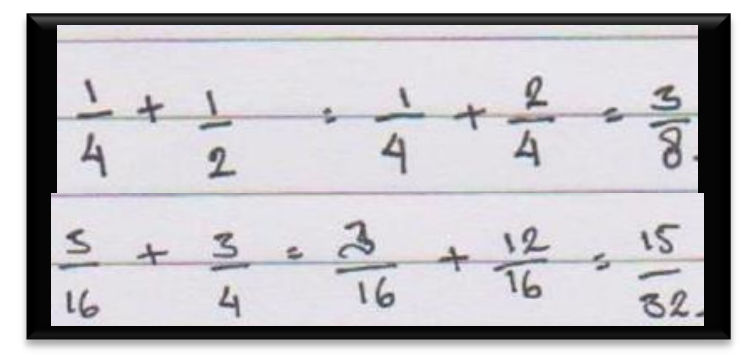

Mahasiswa mengingat semua prosedur menyamakan penyebut pecahan dengan menggunakan KPK. Namun mereka melakukan kesalahan pada langkah terakhir dari prosedur penjumlahan pecahan, dimana mereka menjumlahkan lagi penyebut yang sudah disamakan sebelumnya.

Kesalahan yang terakhir terjadi karena mahasiswa terkecoh dengan berbagai dua algoritma yang berbeda yang diajarkan 
oleh guru, yaitu algoritma menyamakan penyebut dengan KPK, dan algoritma menggunakan rumus:

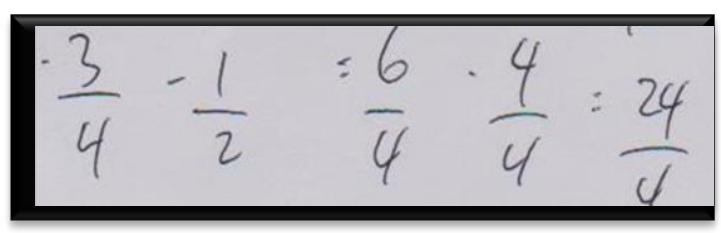

Mahasiswa menggunakan rumus:

$$
\frac{a}{b}+\frac{c}{d}=\frac{(a x d)+(b x c)}{b x d}
$$

Angka 6 pada $\frac{6}{4}$ merupakan hasil kali antara pembilang dari bilangan pecahan pertama dengan penyebut dari pecahan kedua yaitu 2 x 3, sedangkan angka 4 pada pembilang bilangan pecahan $\frac{4}{4}$, merupakan hasil kali antara pembilang bilangan pecahan kedua dengan penyebut bilangan pecahan kedua. Sedangkan untuk bagian penyebut dia menggunakan KPK dari penyebut kedua bilangan pecahan. Langkah terakhir ia mengalikan pembilang kedua bilangan pecahan. Sedangkan penyebutnya merupakan KPK dari penyebut kedua bilangan pecahan.

Semua kekeliruan yang di atas terjadi karena sejak awal mahasiswa menyelesaikan soal dengan cara mengingat kembali langkah-langkah kerja yang diajarkan guru pada jenjang pendidikan sebelumnya. Selain itu, mereka tidak memahami makna bilangan dengan benar. Mereka mengenal bilangan pecahan sebagai sepasang bilangan bulat yang tulis struktur ke bawah dan dipisahkan oleh satu garis datar. Sejak awal mereka diajarkan bagaimana bentuk penulisan bilangan pecahan tanpa mereka harus memahami bagaimana konsep dari bilangan pecahan itu sendiri. Berikut ini adalah soal yang dikerjakan oleh mahasiswa secara berkelompok, dimana 1 kelompok terdiri dari 5 orang. Soal ini diberikan setelah mereka mengerjakan soal operasi formal di atas. Perhatikan jawaban mahasiswa dari 2 kelompok berikut ini:

1. Ibu Tuti memiliki sebuah Kue. la Ingin membagi habis kue tersebut secara adil kepada anak-anaknya. Jika seorang anak mendapat $\frac{1}{4}$ bagian. Berapa orang anak Ibu Tuti semuanya?

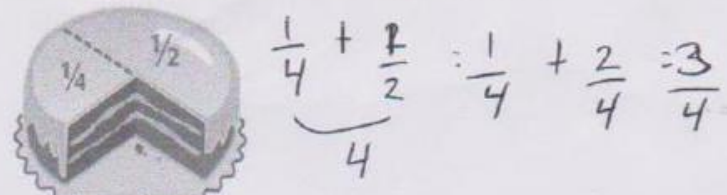

Dari jawaban mahasiswa di atas, dapat diketahui bahwa mahasiswa tidak memahami konsep pecahan. Jika mereka memahami konsep pecahan, tentunya mereka dapat menjawab soal ini dengan mudah. Jawaban mahasiswa lainnya adalah sebagai berikut: 
1. Ibu Tuti memiliki sebuah Kue. la Ingin membagi habis kue tersebut secara adil kepada anak-anaknya. Jika seorang anak mendapat $\frac{1}{4}$ bagian. Berapa orang anak Ibu Tuti semuanya?

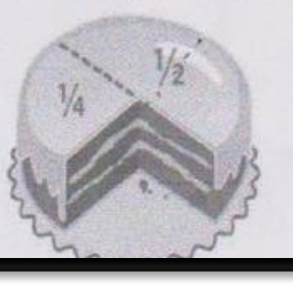

$$
\text { anaknya lbu tuti }=3
$$

Dari jawaban di atas dapat kita lihat bahwa mahasiswa membagi bagian yang $\frac{1}{2}$ menjadi dua bagian yang masing-masing $\frac{1}{4}$. Karena itu mereka berkesimpulan bahwa ibu tuti memiliki 3 orang anak. Karena ada 3 bagian kue yang masingmasing merupakan $\frac{1}{4}$ bagian dari satu buah kue milik ibu Tuti. Pada soal di atas sudah jelas diketahui bahwa ibu Tuti memiliki sebuah kue atau 1 buah kue dan bukan $\frac{3}{4}$ buah kue. Bahkan proporsi dari bagianbagian kue pun sudah tertera pada gambar.

\section{Penutup}

Berdasarkan Hasil di atas, maka dapat disimpulkan bahwa

1. Jenis-jenis kekeliruan mahasiswa adalah: 1). Mahasiswa langsung menjumlahkan bagian Pembilang dengan pembilang dan bagian penyebut dengan penyebut dari dua bilangan pecahan, meskipun kedua bilangan pecahan tersebut memiliki penyebut yang berbeda. Jenis kekeliruan ini dilakukan oleh sebanyak 5\% mahasiswa. 2). Mahasiswa terkecoh dengan dua bilangan pecahan yang pembilangnya sama tetapi penyebutnya berbeda. Karena itu mereka langsung karena itu mereka hanya perlu menjumlahkan penyebutnya saja, sedangkan pembilangnya tidak berubah karena sudah sama. Kekeliruan ini dilakukan oleh 3\% mahasiswa. 3). Sementara $\quad 83 \%$ mahasiswa menyamakan penyebut dari bilangan pecahan dengan menggunakan KPK tetapi mereka lupa cara merubah pembilang apabila penyebutnya berubah. 4). Kekeliruan keempat ini hanya dilakukan oleh 5\% mahasiswa dimana mereka menyelesaikan soal dengan menggunakan rumus, namun mereka menggunakan rumus operasi perkalian pada operasi pengurangan. Sisahnya 4\% mahasiswa menjawab benar dengan cara menyamakan penyebut dengan menggunakan KPK.

2. Berdasarkan pekerjaan mahasiswa dan hasil wawancara diketahui bahwa penyebab kekeliruan yang dilakukan oleh mahasiswa adalah mereka menghafal prosedur kerja yang diberikan guru dalam menyelesaikan soal tentang pecahan. Karena itu mereka melakukan kesalahan saat mengingat kembali prosedur atau langkah-langkah kerja. Mereka juga berasal dari SMK pertanian yang tersebar di seluruh NTT sehingga 
mereka tidak terlalu fokus pada materi pelajaran matematika.

\section{DAfTAR PUStaka}

[1] L. Susan, Rational Numbers and Proportional Reasoning, In second Handbook of Research on Mathematics Teaching and Learning, pp. 68-629, Reston, VA: National Council Of Teachers of Mathematics, 2007.

[2] Clarke, M. Doug, Anne Roche, Annie Mitchell, and Michal Sukenik. Assessing Students Understanding of Fractions Using Task Based Interviews", In Proceeding of the 30th Conference of International Group of Psychology of Mathematics Education, pp. 44-337, 2006.

[3] B. De Castro, Pre-Service Teachers' Mathematical Reasoning As An Imperative For Codified Conceptual Pedagogy In Algebra: A case study in teacher education. Asia Pacific Education Review, 5(2). 57-166, 2004.

[4] Nenden, Design Research on Developing a Beginning Understanding of Multiplication Fraction by Whole Number in Grade Five Primary School Students in Indonesia, Master Tesis, Universitas Sriwijaya, 2010.

[5] Surya, 2010.

[6] H. Freudenthal, 1983.

[7] Kennedy, 1994.

\section{Riwayat Hidup PenUlis}

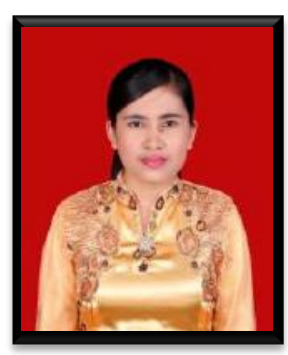

Sri Imelda Edo, M.Pd.. Staf pengajar di Politeknik Pertanian Negeri Kupang. Studi S2 Pendidikan Matematika Universitas Sriwijaya Palembang, lulus tahun 2011. 
This page is intentionally left blank 